\title{
Attracting Customers Interest through Celebrity Endorses for Marketplace
}

\author{
Defin Shahrial Putra ${ }^{\circledR 1}$, Farida Yulianti ${ }^{2}$, Abdurrahim ${ }^{3}$ \\ Faculty of Economics, Universitas Islam Kalimantan Muhammad Arsyad Al Banjari, Banjarmasin, \\ Indonesia ${ }^{1,2,3}$
}

\section{Info Article}

History Article:

Submitted 03 January 2020

Revised 05 February 2020

Accepted 18 February 2020

Keywords:

Celebrity Endorse; Brand

Awareness; Purchase Interest;

Marketplace.

\begin{abstract}
This study aims to determine the tendency of celebrity endorse mediated by brand awareness impact to attract buying interest from the public. This is because celebrities are people who are well known to the public and have there are charm. So that with the support of celebrities will have an impact on the sale of their products. Some marketplaces use celebrities as brand ambassadors to attract buyers, besides it will give celebrity brands that are constantly remembered by customers. In this study because the population is unknown, the sampling technique uses purposive sampling as many as 310 respondents. The analysis technique used is Structural Equation Modeling (SEM). The results show that brand awareness mediates the influence of celebrities on customer interest when a celebrity carries advertisements will give the impression to customers that the celebrity has a good reputation and attractiveness will have a good impact. Besides the marketplace in choosing a celebrity will look for those who can deliver advertisements with professionals. The implication of this research is the need for celebrity support related to the importance of attracting people's purchasing power to the marketplace, in addition to a well-known combination of a good reputation and attractive appearance has added value that will provide reminders to customers.
\end{abstract}

\section{Menarik Minat Pelanggan melalui Dukungan Selebriti bagi Pasar}

\begin{abstract}
Abstrak
Penelitian ini bertujuan untuk mengetahui kecenderungan celebrity endorse yang dimediasi brand awareness dampaknya untuk menarik minat beli dari masyarakat. Hal ini dikarenakan, selebriti merupakan orang yang banyak dikenal masyarakat dan memiliki daya tarik tersendiri. Sehingga dengan adanya dukungan selebriti akan berdampak terhadap penjualan produk mereka. Beberapa marketplace menggunakan selebriti sebagai duta merek untuk menarik pembeli, selain itu akan memberikan merek yang di bawa oleh selebriti diingat oleh pelanggan secara terus menerus. Dalam penelitian ini karena populasi tidak diketahui, teknik pengambilan sampel menggunakan purposive sampling yaitu sebanyak 310 sampel responden. Teknik analisis yang digunakan adalah Structural Equation Modeling (SEM). Hasil penelitian menunjukkan bahwa brand awareness memediasi pengaruh selebriti terhadap minat pelanggan, ketika seorang selebriti membawakan iklan akan memberikan kesan kepada pelanggan bahwa selebriti tersebut memiliki reputasi baik dan memiliki daya tarik akan memberikan dampak yang baik. Selain itu marketplace dalam memilih seorang selebriti akan mencari yang dapat membawakan iklan dengan profesional. Implikasi penelitian ini adalah perlunya dukungan selebriti terkait pentingnya menarik daya beli masyarakat bagi marketplace, selain seorang yang terkenal kombinasi reputasi yang baik dan berpenampilan menarik mempunyai nilai tambah yang akan memberikan pengingat pada pelanggan.
\end{abstract}

JEL Classification: M3, P4

How to Cite: Putra, D. S., Yulianti, F., \& Abdurrahim. (2020). Attracting Customers Interest through Celebrity Endorses for Marketplace. Jurnal Dinamika Manajemen, 11(1), 84-92. 
Defin Shahrial Putra et al./ Attracting Customers Interest through Celebrity...

\section{INTRODUCTION}

Competition in the modern era is increasingly fierce due to the rapid development in technology and the demographic shifts and economic conditions that have triggered changes in the complex business environment. Competitiveness is determined by the firm ability to develop and understand organizational change. It involves a combination of thought processes and the use of technology in producing something different or better than competitors.

Technology provides facilities and convenience in selling through internet media. The ease that is given to consumers to carry out various activities, such as finding information, communicating and as a means of shopping. Through internet shopping or online shopping, a buyer can first see the goods and services. This product is promoted by the seller and then makes a deal first then the products and services can be sent quickly through third-party shipping packages. In addition to provides convenience for online buyers, social media is exciting. It prove that the internet is very efficient, practical and can save time to market products and services.

Endorser of a social media influencer is considered as an effective way to promote products and services. Attributes that they have such as expertise, skills, knowledge, experience, intelligence, character, beauty, courage and achievement can be used as important points to attract (potential) consumers (Fleck et al., 2012; Pradhan et al., 2014). Celebrity endorsers are used to attract the attention of the public and are expected to increase product awareness. The use of celebrity endorsers gives the impression that consumers are selective in choosing and improving status by owning what is used by celebrities (Pradhan et al., 2014).

Some online stores use celebrity as a brand ambassador to attract buyers. Tokopedia is an online service company that is included in the marketplace category which allows every buyer and business owner in Indonesia to communicate their online business. Its efficient and free, as well as a more secure and comfortable online shopping experience (Pratisti, 2015).
Besides the celebrity endorser variable has a significant influence on buying interest in Elevenia by recruiting Raisa as a celebrity endorser, where the majority of respondents stated that Raisa has advantages such as physical attractiveness, expertise in the arts, especially the world of singing, and reputation as an endorser who previously was also very well. Because of that Elevenia needs to maintain Raisa celebrity endorser they remember the many benefits obtained by the company (Kismantoro, 2017).

The results obtained show that celebrity endorsers have a positive influence on buying interest (Mubarok, 2016). The use of celebrity can provide attraction so that it influences in increasing interest in buying a product. Trust in celebrity endorsers also influences on increasing interest in buying a product. The expertise possessed by a celebrity endorser can have a positive influence on buying interest.

Gupta (2014) shows that celebrity support is one of the useful tools to promote products to customers. Customers tend to be attracted to advertisements that use celebrity endorsers which not only promote the products but also help in public awareness of brands or products. Thus companies must very selectively try to match the product attributes with the celebrity that will be used.

The use of celebrity endorses and company pricing strategies are expected to influence brand awareness. Brand awareness or brand awareness is the first step to building a product brand. Brand awareness shows consumer knowledge of the existence of a brand. Purchase interest is obtained from a learning process and thought the process that forms a perception. This research has novelty of how buying interest creates a motivation that is recorded continuously in the mind of the customer and becomes a powerful desire.

\section{Hypothesis Development Celebrity Endorse Affects Brand Awareness of Tokopedia's E-Commerce Products}

This study uses the effectiveness of advertising variables as a factor that influences brand awareness, where effective advertising can be 
received by considering endorsers, advertising messages and advertising media.

Research Celebrity endorser variables consisting of trust, expertise, attractiveness, respect, and similar (simultaneous) similarity have a significant positive effect on L'oreal brand image. According to Mowen and Minor (2002), endorse are the characteristics or features possessed by the object. So the endorse attribute is a characteristic or trait that owned by the endorser. Two key factors determine the effectiveness of the communication process is, namely, the characteristics of the information source (endorse) and the features of the message being informed.

The result of Sintani's research (2016), explains that the influence of the use of celebrity endorses Isyana Sarasvati in Tokopedia Media "Isyana vs Gangster" on brand awareness in Surabaya. The results of this study prove that the use of celebrity endorser Isyana Sarasvati in Tokopedia Advertisements "Isyana vs Gangster" influences Surabaya Brand Awareness. Based on this finding, the following hypothesis is formulated.

$\mathrm{H} 1$ : Celebrity endorse is positively affecting brand awareness.

\section{Celebrity Endorsement Influences the Pur- chase Intention of Tokopedia's Products}

Celebrity endorsement is considered advertisement support to convey the promotional message. Endorse is often also referred to as a direct source (direct source), which is a speaker who delivers a message and demonstrates a product or service. Besides, endorser could be interpreted as the person employed to represent the image of a product (product image). It usually have strong characters that stand out appeal (Belch, 2009).

Research (Ismantoro, 2017) states that the celebrity endorser variable significantly influences the buying interest variable. This means Raisa as a celebrity endorser from Elevenia can attract consumers to buy on online websites.

Schiffman and Kanuk (2010), interest is one of the psychological aspects that has a considerable influence on behavioral attitudes. At- tention is also a source of motivation and directs someone to do an activity or action. Buying interest is one of a mental activity that arises because of feelings (affective) and thoughts (cognitive) of an item or service desired.

$\mathrm{H} 2$ : Celebrity endorse is positively affecting the purchase intention

\section{Brand Awareness Influences the Interest in Purchasing E-Commerce Products of Toko- pedia}

Research by (Yaseen et al., 2011) shows that a significant impact of brand awareness and loyalty while a significant impact on perceived quality on profitability. Furthermore, the results show a significant impact of brand awareness, perceived quality, and loyalty on purchase intentions.

Chi et al. (2009), stated that the higher brand awareness would result in higher purchase intentions, so brand awareness positively and significantly influences buying intentions. Buying interest is the tendency of consumers to buy a brand or take action related to the purchase as measured by the level of the likelihood of consumers making a purchase (Assael, 2001).

H3: Brand awareness is positively affecting customer purchase intention.

\section{Brand Awareness Mediates the Effect of Ce- lebrity Endorsement on the Interest in Bu- ying E-Commerce Products in Tokopedia}

The purpose of Hsin et al. (2015) is to explore the effects between brand awareness, perceived quality, brand loyalty and purchase intention by consumers and the mediating result of perceived quality and brand loyalty on brand awareness and buying intentions. Samples were collected from cell phone users living in China, and the study adopted a regression analysis. This study shows that cell phone manufacturers must build brands and increase brand awareness through sales promotion, advertising, and other marketing activities. When brand awareness is high, brand loyalty will also increase. Consumers will evaluate the perception of product quality from their purchasing experience. As a 
Defin Shahrial Putra et al./ Attracting Customers Interest through Celebrity...

result, brand awareness, brand loyalty, and preferences will also increase purchase intentions.

$\mathrm{H} 4$ : Brand awareness is positively mediating the effect of celebrity endorsement on customer purchase intention.

\section{METHOD}

\section{Research Design}

This research is a quantitative study which is a research that requires the use of numbers, starting from data collection, interpretation of the data, and the discovery of the results. This research is a one-shot study or cross-sectional study. Cross-sectional research is research that can be done by collecting data once, maybe through a period, time in a few days or a few weeks or a few months to answer questions in a study (Sekaran \& Bougie, 2013).

\section{Population and Research Samples}

The population is a combination of all elements that have a set of similar characteristics that include the universe for the benefit of research problems, the population in this study is all consumers who have shopped at Tokopedia. While the sample is part of a population consisting of sample units (Malhotra, 2010). Then the sampling unit used in this study is consumers who have shopped.

The sampling method used in this study is the purposive sampling method. According to Sekaran and Bougie (2013), purposive sampling is a method that is limited to the types of people who can provide the information needed, it can be due to only certain types of people who have the information or the type of person matches the criteria determined by researchers. By using this purposive sampling method, it will be easier for authors to choose respondents to be sampled because researchers can choose respondents more specifically in the sampling process.

The determination of the minimum sample size in this study refers to the statement of Hair et al. (2010) that the number of samples as respondents must be adjusted to the number of question indicators used in the questionnaire, assuming $\mathrm{n} \times 5$ observed variables (indicators) up to $\mathrm{n} \times 10$ observed variables (indicators). In this study the number of items was 31 question items used to measure 3 variables, in this study the authors used $\mathrm{n} \times 10$. The number of respondents used was 31 statement items multiplied by 10 equal to 310 respondents.

In this study, the data will be analyzed using the structural equation model (SEM) method which is a multivariate statistical technique that combines aspects in multiple regression aimed at testing the dependent relationship and factor analysis that presents the concept of immeasurable factors with multi variables used to estimate a set of dependent relationships that influence each other together (Hair et al., 2010).

\section{RESULT AND DISCUSSION}

\section{Results \\ Validity Test Results}

A validity test is done to determine whether an indicator is valid or not valid (Malhotra, 2010). One indicator that is validated is approved. The higher the validity, the higher the level of validity of an indicator. The question was declared valid considering the loading factor was greater than 0.5 (Hair et al., 2010).

Table 1 presents the results of the analysis testing the validity of statement items, that no statement items were discarded because they all had a loading factor above 0.5 and were said to be valid because $r_{\text {count }}$ was greater than $r_{\text {table }}$.

\section{Reliability Test Results}

A reliability test is carried out to determine the level of reliability of a study. Reliability is a measurement tool for a questionnaire which is an indicator of a variable or construct (Malholtra, 2010). The level of reliability can be seen from the answers to a statement that is consistent and stable. Cronbach alpha is a measure in measuring the correlation between the answer statements of a constructor variable conside- 
Table 1. Validity Test Results

\begin{tabular}{|c|c|c|c|}
\hline Indicator & $\mathbf{r}_{\text {count }}$ & $\mathbf{r}_{\text {table }}$ & Note \\
\hline $\mathrm{X}_{1.1}$ & .326 & .095 & Valid \\
\hline $\mathrm{X}_{1.2}$ & .277 & .095 & Valid \\
\hline $\mathrm{X}_{1.3}$ & .365 & .095 & Valid \\
\hline $\mathrm{X}_{1.4}$ & .338 & .095 & Valid \\
\hline $\mathrm{X}_{1.5}$ & .227 & .095 & Valid \\
\hline $\mathrm{X}_{1.6}$ & .268 & .095 & Valid \\
\hline $\mathrm{X}_{1.7}$ & .344 & .095 & Valid \\
\hline $\mathrm{X}_{1.8}$ & .396 & .095 & Valid \\
\hline $\mathrm{X}_{1.9}$ & .264 & .095 & Valid \\
\hline $\mathrm{X}_{1.10}$ & .290 & .095 & Valid \\
\hline $\mathrm{X}_{1.11}$ & .329 & .095 & Valid \\
\hline $\mathrm{X}_{2.1}$ & .318 & .095 & Valid \\
\hline $\mathrm{X}_{2.2}$ & .274 & .095 & Valid \\
\hline $\mathrm{X}_{2.3}$ & .252 & .095 & Valid \\
\hline $\mathrm{X}_{2.4}$ & .334 & .095 & Valid \\
\hline $\mathrm{X}_{2.5}$ & .328 & .095 & Valid \\
\hline $\mathrm{X}_{2.6}$ & .362 & .095 & Valid \\
\hline $\mathrm{X}_{2.7}$ & .202 & .095 & Valid \\
\hline $\mathrm{X}_{2.8}$ & .201 & .095 & Valid \\
\hline $\mathrm{X}_{2.9}$ & .318 & .095 & Valid \\
\hline $\mathrm{X}_{2.10}$ & .302 & .095 & Valid \\
\hline $\mathrm{X}_{2.11}$ & .224 & .095 & Valid \\
\hline $\mathrm{X}_{2.12}$ & .298 & .095 & Valid \\
\hline $\mathrm{X}_{2.13}$ & .333 & .095 & Valid \\
\hline $\mathrm{Y}_{1}$ & .356 & .095 & Valid \\
\hline $\mathrm{Y}_{2}$ & .369 & .095 & Valid \\
\hline $\mathrm{Y}_{3}$ & .294 & .095 & Valid \\
\hline$Y_{4}$ & .436 & .095 & Valid \\
\hline$Y_{5}$ & .349 & .095 & Valid \\
\hline $\mathrm{Y}_{6}$ & .410 & .095 & Valid \\
\hline $\mathrm{Y}_{7}$ & .466 & .095 & Valid \\
\hline
\end{tabular}

Table 2. Reliability Test Result

\begin{tabular}{lll}
\hline Variable & $\begin{array}{l}\text { Reliability } \\
\text { Coefficient }\end{array}$ & Remarks \\
\hline $\begin{array}{l}\text { Celebrity } \\
\text { Endorse }\left(\mathrm{X}_{1}\right)\end{array}$ & .662 & Reliable \\
\hline Brand & .657 & Reliable \\
Awareness $\left(\mathrm{X}_{2}\right)$ & & \\
\hline $\begin{array}{l}\text { Purchase } \\
\text { Interest }(\mathrm{Y})\end{array}$ & .678 & Reliable \\
\hline
\end{tabular}

red reliable if the Cronbach alpha value is $\geq 0.6$ (Malhotra, 2010).

Based on Table 2 it can be seen that the reliability test conducted shows that all variables are declared reliable. This can be concluded by seeing that each variable has a Cronbach alpha value equal to or more than 0.6. This indicates that all statements made were considered appropriate and could be used for research purposes. 
Defin Shahrial Putra et al./ Attracting Customers Interest through Celebrity...

Table 3. Goodness of Fit Index

\begin{tabular}{llll}
\hline Criteria & Results & $\begin{array}{l}\text { Cut Off } \\
\text { Value }\end{array}$ & Conclusion \\
\hline Chi- & 68.179 & Minor & Good \\
Square & & & \\
p-value & .921 & $\geq .05$ & Good \\
RMSEA & .000 & $\leq .08$ & Good \\
GFI & .966 & $\geq .90$ & Good \\
AGFI & .952 & $\geq .90$ & Good \\
CMIN/ & .86 & $\leq 2,00$ & Good \\
DF & & & \\
TLI & 2.730 & $\geq .95$ & Good \\
CFI & 1.000 & $\geq .95$ & Good \\
\hline
\end{tabular}

\section{Hypothesis Test}

Hypothesis testing is performed to determine whether or not the independent variable influences the dependent variable.

According to Table 3, it can be seen that the results of chi-square are 68.179 with probability $0.921 \geq 0.05$, RMSEA value is $0.000 \leq 0.08$, GFI value is $0.966 \geq 0.90$, AGFI value is $0.952 \geq 0.90$, CMIN / DF value of $0.86 \leq 2$, TLI value of 2.730 $\geq 0.95$, and a CFI value of $1 \geq 0.95$, which indicates that the model's suitability test can be well received. So in this study, it can be concluded that the structure of modeling analysis can be done.

Based on 8 parameters, the value of goodness of fit index of seven parameters of the goodness of fit is classified as good, so it can be said that the SEM model as a whole is fit (there is a match between the model and data). based on Table 4, the relationship between variables can be explained as follows.

\section{The Influence of Celebrity Endorse on Brand Awareness}

The results showed that the regression coefficient of celebrity endorses to brand awa- reness. This analysis illustrates that the regression coefficient is significant because the P-value (probability) is less than 0.05 . These results provide the conclusion that the research data support the direct influence of celebrity endorsement on brand awareness. Thus the $\mathrm{H} 1$ research hypothesis in this study was accepted.

\section{Influence of Celebrity Endorse on Purchase Interest}

The results of data processing note that the P-value (probability) of 0.001 . These results meet the requirements, which is less than 0.05; these results provide the conclusion that the research data support the direct influence of celebrity endorse on buying interest. So it can be concluded $\mathrm{H} 2$ in this study can be accepted

\section{The Influence of Brand Awareness on Pur- chase Interest}

Data from the research shows that the results of data processing are known that the Pvalue (probability) of 0.001 . These results meet the requirements of less than 0.05 . These results support the direct influence of brand awareness on buying interest. Thus the $\mathrm{H} 3$ research hypothesis in this study was accepted.

\section{Brand Awareness Mediates the Effect of Ce- lebrity Endorse on Purchasing Interests}

Hypothesis testing in this section depends on the results of statistical tests on two channels, namely: (1) the path of celebrity endorse to brand awareness and (2) the path of brand awareness to purchase interest. This hypothesis is proven if the two pathways are significant, as explained in the hypothesis $\mathrm{H} 1$ and H3. The results of statistical tests on these two pathways are significant because the P-value is less than alpha 0.05 , and for the indirect effect

Table 4. Hypothesis Test

\begin{tabular}{|c|c|c|c|c|c|c|c|}
\hline & & & Estimate & S.E. & C.R. & $\mathbf{P}$ & Label \\
\hline Brand_Awareness & $<--$ & Celebrity_Endorse & 2.325 & 1.843 & 4.262 & $* * *$ & Significant \\
\hline Purchase_Interest & $<---$ & Brand_Awareness & 3.176 & 2.712 & 5.667 & $* * *$ & Significant \\
\hline Purchase_Interest & $<---$ & Celebrity_Endorse & 1.174 & 1.622 & 3.724 & $* * *$ & Significant \\
\hline
\end{tabular}


of celebrity support on buying interest through brand awareness it appears that it is proven to mediate at 0.563 . Thus, the $\mathrm{H} 4$ research hypothesis can be accepted.

\section{Discussion}

SEM analysis results on the first hypothesis testing showed that the celebrity endorse variable had a direct impact on the brand awareness of Tokopedia e-commerce products. This finding is in line with previous research which stated that celebrity endorser Isyana Sarasvati in Tokopedia Ads "Isyana vs. Gangster" influences Brand Awareness of Surabaya Society (Sintani, 2016).

The results of this study indicate that there is a direct influence of celebrity endorsement on brand awareness. It means that the selection of an artist in a product advertisement could influence the customer brand's memory, such as reputation, the appeals of the artist. Thus, brand awareness is reflected through the visual memory of the company images. This step is essential for the initial stages of respondents to be familiar with the brand, and until each will make an online purchase will always remember the brand.

Based on the statistical results of the study above, obtained celebrity endorse significantly influences the purchase interest. So, it can be concluded that celebrity endorse affects the purchase interest of Tokopedia e-commerce products. This finding indicates that if the artist who becomes an icon in a product has a good reputation, it will make respondents interested in the products. The artist attraction is referred to as an artist character considered as a new object concerning the concept of a particular group with physical attractiveness. Someone attractive feels more positive and reflects the brand being advertised better than people with the average appeal. Previous research conducted by Ahmed (2016), also explained that endorse credibility assessed from attractiveness, trustworthiness, and expertise had a positive influence on the attractiveness of advertisements.

Based on the results of the research statistics above, obtained brand awareness has a significant effect on buying interest. So, it can conclude that brand awareness influences the purchase interest of Tokopedia e-commerce products. Empirically the results of this study prove that the introduction of a brand the starting point of a consumer will recognize the brand. A consumer in knowing a brand will surely dig up information about the brand first, and if the review is useful, it will decide to buy. And will also make repeated purchases, up to recommend it to others because they have trusted the brand.

Chi et al. (2009) state that higher brand awareness will result in higher purchase intentions, so brand awareness positively and significantly influences buying intentions. This finding is supporting the results (Jalilvand et al., 2011; Shah et al., 2012), which indicate that brand awareness had a significant positive effect on purchase intention. Brand awareness has a significant positive relationship with consumer purchase intentions (Yaseen et al., 2011; Malik et al., 2013; and Roozy et al., 2014).

In the previous discussion, it was explained that the direct influence channel of celebrity support, brand awareness, and buying interest is significant. But there is also an indirect effect of celebrity support on the intention to purchase e-commerce products that are mediated by brand awareness. Brand awareness in the form of recognition and recall is a mediator that acts as a stimulus for consumers to trust brands and make purchases. The results of this study indicate that brand awareness mediates the influence of celebrities on buying interest. These findings indicate that this research proves the indirect effect of celebrity support on buying interest in Tokopedia e-commerce products.

The results of the study show that it not only mediate the effect of celebrity endorsement on purchase intention. It also proves that the presence of brand awareness can make a consumer remember the brand. When the customer reminds the brand of the product, it possibly can make a continuous purchase. Also, the reputation of a public figure can encourage a consumer to trust the brand being advertised. 
Defin Shahrial Putra et al./ Attracting Customers Interest through Celebrity...

\section{CONCLUSION AND RECOMMENDATION}

Purchase interest made by a consumer is the impact of an artist who carries the Tokopedia ad so that it will make the brand in consumers' minds. Companies that have the right products will look for an artist who can deliver product advertisements professionally. The attitude of brand recognition and brand recall in forming a brand has an impact on buying interest.

Wherewith the brand recognition attitude, a consumer will understand the product, and then will decide to buy. And if the consumer feels satisfied, he will indirectly make a purchase or remember the brand. Brand awareness can roled as a mediating variable, enhancing the celebrity endorses to increase purchase interest. When a public figure carries a product advertisement, it will give the impression to consumers that the artist has a good reputation and has an appeal by using products carried in the ads. So that it will have an impact considering the brand and will carry out increased buying interest. It is expected that Tokopedia always pays attention to the public figures who carry their advertisements.

In this research, it was revealed that brand awareness could be a variable in encouraging buying interest. In addition to celebrity endorsement, because the combination of a good reputation in public figures will give brand reminders to consumers. The results of this study also found that an attractive public figure has added value to the purchase interest

In addition to the celebrity endorse that the company does to attract consumers, the brand created by the company must have its own or another appeal from competitors. Because the role of celebrity endorsement is not the main factor influencing buying interest but brand awareness is also an indirect influence affecting buying interest.

However, this research has several limitations. The level of generality may give different results due to the research area is only take place in Banjarmasin city. Future studies may include the demography as a control variable. Besides,
The brand image of the online store itself is also an important aspect to be explored.

\section{Acknowledgment}

The author would like to give great appreciation to all of the laboratory helpers during the research. This research is fully funded by the Islamic University of Kalimantan under the supervision of the bureau of research and community service.

\section{REFERENCES}

Ahmed, R., Seedani, S., Ahuja, M., \& Paryani, S. (2016). Impact of Celebrity Endorsement on Consumer Buying Behavior. SSRN Electronic Journal, 16(September), 12-22.

Arikunto, S. (2010). Prosedur Penelitian Suatu Pendekatan Praktik. Jakarta: Rineka Cipta.

Assael, H. (2001). Customer Behavior and Marketing Action 6 th Edition. New York: NYU Thomson Learning.

Belch, G. E., Belch, M. A. (2009). Advertising and Promotion: an Integrated Marketing Communication Perspective. 8th Edition. New York: Mc Graw-Hill.

Bougie, R., \& Sekaran, U. (2013). Research Methods for Business: a Skill Building Approach. New York: John Wiley \& Sons.

Chi, H. K, Yeh, H. R., \& Yang, Y. Y. (2009). The Impact of Brand Awareness on Consumer Purchase Intention: the Mediating Effect of Perceived Quality and Brand Loyalty. The Journal of International Management Studies, 4(1),135-144.

Gupta, T. (2014). Impact of Celebrity Endorsement on Purchase Decision: a Study among Youth of Bareilly. International Journal of Management, 4(3), 1041-1046.

Hair Jr, J. F., Black, W. C., Babin, B. J., Anderson, R. E., \& Tatham, R. L. (2006). Data Analysis Multivariate. New Jersey: Prentice Hall.

Ismantoro, A. J. (2016). Pengaruh Celebrity Endorser, Kreativitas Iklan dan E-Service Quality terhadap Minat Beli di Situs Belanja Online Elevenia. Co. Id. Thesis. UIN Syarif Hidayatullah Jakarta.

Jalilvand, M. R., Samiei, N., Mahdavinia, S. H. (2011). The Effect of Brand Equity Compo- 
nents on Purchase Intention. International Business and Management, 2(2), 149-158.

Lemeshow, S., Hosmer, D. W., Klar, J., \& Lwanga, S. K. (1997). Besar Sampel dalam Penelitian Kesehatan. Yogyakarta: Gajah Mada University.

Malhotra, N. K. (2010). Marketing Research: an Applied Orientation Six ${ }^{\text {th }}$ Edition. New York: Pearson Education.

Mowen, J. C., \& Minor, M. (2002). Perilaku Konsumen. Jakarta: Erlangga.

Mubarok, D., \& Aziz, A. (2016). Pengaruh Celebrity Endorsement terhadap Minat Beli Konsumen (Studi pada Konsumen Mahasiswa kelas Reguler Sore STIE INABA Bandung). Jurnal Indonesia Membangun, 3(1), 1-16.
Schiffman, L. G., \& Kanuk, L. L. (2010). Consumer Behavior Tenth Edition. New Jersey: Pearson Education.

Sintani, L. (2016). Pengaruh Penggunaan Celebrity Endorser Isyana Sarasvati dalam Iklan "Isyana vs Gangster” terhadap Brand Awareness Masyarakat Surabaya. Jurnal E-Komunikasi, 4(1), 1-10.

Yaseen, Nazia. Mariam Tahira. Amir Gulzar (Corresponding Autor) \& Ayesha Anwar. (2011). Impact of Brand Awareness, Perceived Quality and Customer Loyalty on Brand Profitability and Purchase Intention: A Resellers's view. Journal of Contemporary Research in Business, 3(8), 833-839. 